\title{
Influence of Spent-Engine Oil on Hematology, Renal and Liver Status of Auto- Mechanics of Benin-City, Nigeria
}

\section{*11OMOROWA, FE; AGU, KC; OKOLIE, NP; OGHAGBON, SE; SULE, AS; EGBUTA, UM}

Department of Medical Biochemistry, School of Basic Medical Sciences, College of Medical Sciences, University of Benin, 300001,Benin City.

\begin{abstract}
This study was aimed at assessing the effects of spent engine oil on hematological parameters, renal and liver status of auto-mechanics. A questionnaire was design and blood sample was collected from both auto-mechanics and non-mechanics. The response from the questionnaire indicated complaints of pains around thoracic region, skin rashes etc; unawareness of the detrimental contents of spent engine oil; poor precautionary and sanitary practices. Assessment of renal status indicated that plasma urea and creatinine levels for auto-mechanics $(18 \mathrm{mg} / \mathrm{dl}$ and $0.81 \mathrm{mg} / \mathrm{dl}$, respectively) were significantly higher compared to non-mechanics $(16 \mathrm{mg} / \mathrm{dl}$ and $0.68 \mathrm{mg} / \mathrm{dl}$, respectively). Haematological profile of the auto-mechanics compared to non-automechanics showed that packed cell volume increased significantly (41\%) for auto-mechanics compared to non-automechanics (39\%); haemoglobin concentration increased significantly $(14.3 \mathrm{~g} / \mathrm{dl}$ compared to $13 \mathrm{~g} / \mathrm{dl})$; and neutrophils increased significantly (34\% compared to 26\%). Though, lymphocytes increased $(65.9 \%)$ compared $(65.5 \%$, for non-automechanics), this was not significant $(\mathrm{p}=0.850)$. Neutrophils $(\mathrm{p}<0.05)$ and lymphocytes $(\mathrm{p}=0.850)$ increased for the automechanics $(33.5 \%$ and $65.9 \%$, respectively) compared to the non-automechanics $(26.4 \%$ and $65.5 \%$, respectively). Alkaline phosphatase activity increased (19.7U/l) compared to (16.6U/1, non-automechanics); while aspartate transaminase and alanine transaminase significantly decreased (13.4U/1 and $7.4 \mathrm{U} / 1$, respectively) compared to (9.7U/1 and 4.8U/1, respectively). Thus, the uses of hygienic protective practices are encouraged like the use of face and nose mask, and auto-mechanics are encouraged to go for regular medical check-up. (C) JASEM
\end{abstract}

http://dx.doi.org/10.4314/jasem/v19i3.6

KEY WORDS: Auto-mechanics; Polycyclic aromatic hydrocarbons (PAHs); Spent engine oil; Questionnaire.

\section{Introduction}

Engine oil is refined from crude oil or synthetic oil for lubricating of combustion engines. It also cleans, inhibits corrosion, improves sealing and cools the engine by carrying heat away from moving parts. Engine oil, are composed of a virgin base of oil (a complex mixture of hydrocarbons, $80-90 \%$ by volume) and performance enhancing additives (10$20 \%$ by volume) (Collins, 2007). The term, spent engine oil (SEO), also known as used mineral-based crankcase oil, refers to any lubricating oil that has served its service properties in a vehicle, withdrawn from the meant area of application and considered not fit for its initial purpose (Kojernikova, 1999). This used mineral-based crank case oil is found to be used among auto-mechanics all over Nigeria. These used lubricants contain a lot of toxic and carcinogenic substance that can be detrimental to the ecosystem, which include, pollution of water and soil by way of surface run-off and spillage which affects the growth of plants and aquatic organisms by impairing with its film natural processes such as oxygen replenishment and photosynthesis and also affects humans who consume food from their natural environment.
In a crankcase-lubricated engine, the oil compartment acts as a sink for heavy molecular weight incomplete combustion products such as polycyclic aromatic hydrocarbons (PAHs) and their analogs. This contaminant, PAHs and the others which are formed via combustion, can accumulate in the oil by a factor of up to 1,000. PAHs are known to be highly toxic environmental contaminants with carcinogenic and mutagenic properties. These PAHs are also present in much lower quantities in new or fresh oil (Van Donkelaar, 1990). Used mineral-based crankcase oil, waste crankcase oil or used motor oil is another name for spent engine oil. It is the brown-to-black, oily liquid removed from the engine of a motor vehicle when the oil is changed. Used mineral-based crankcase oil is a complex mixture of metals and PAHs. When motor oils undergo thermal decomposition, gasoline combustion products are formed, significantly increasing the levels of PAHs which contribute to the carcinogenic and mutagenic properties of the oils (Ingram et al., 1994), and various additives that improve the performance of the oil in the engine such as polychlorinated biphenyls, chlorodibenzofurans, lubricative additives, decomposition products. In addition to the chemicals 
found in unused oil, used mineral-based crankcase oil contains chemicals that are formed when the oil is exposed to the high temperatures and pressures inside an engine as it runs. In addition, used mineral-based crankcase oil contains small amounts of water, gasoline, antifreeze, and chemicals that come from gasoline when it burns inside the engine, but most of the chemicals found in the oil do occur naturally., lead, manganese, nickel, and silicon that come from engine parts as they wear down (ATSDR, 1997 ). The effect of discharged spent engine oil on the environment is poorly understood and only limited data exist and these are not readily available (Odjegba and Atebe, 2007).

Auto mechanics are exposed to residual used gasoline engine oils that accumulate on automobile parts, tools, work-benches, floors and equipment. The local consumption of engine oil in Nigeria is increasing at a very high rate due to the drastic increase in vehicles and other machines that make use of this lubricant thus increasing the chances of exposure of this class of workers to lead (Pachathundikani and Varghese, 2006). Polycyclic aromatic hydrocarbons (PAH) compounds can be readily absorbed through the skin and for automotive mechanic; this may be the major route of entry. The increased cancer risk may be directly related to the constant contact of the hands and forearm of automotive mechanics to these carcinogenic substances (Boffetta et al., 1997). The chemical pollutants from gasoline vapours (and spent engine oil), like other known xenobiotics, may be metabolically transformed into various metabolites in the body (Hu and Wells, 1994). Some of these metabolites may be very reactive, interacting in various ways with the metabolizing and excreting tissues (mainly the liver and kidneys) to elicit toxic effects (Page and Mehlman, 1989; Nygren et al., 1994). Thus, a data base of the level of awareness and toxicity profile of spent engine oil can be generated and documented so that the populace, automechanics, health workers and various stake-holders in government can be better oriented and equipped towards reducing the possible negative health and environmental effects of spent engine oil.

\section{MATERIALS AND METHODS}

Subjects: The study was carried out within a period of one month and subject inclusion criterion was based on the fact that, there were no recorded cases or history of ill-health, not handicapped, observed to be healthy by visual and clinical observations, etc. A total of sixty subjects were finally selected for the research made up of mostly male participants as the test subject and few females with their age ranging from 20years to 60years. 30 of the subjects were auto-mechanics (tests) while 30 were students of University of Benin and were used as control. The test (auto-mechanic) and control subjects located around Benin City metropolis were properly informed and enlightened about the research and made to fill and sign a consent form. They were also given questionnaires to fill so as to obtain their level of awareness about spent engine oil and their possible effects.

Blood sample collection and biochemical assays: Blood samples $(5 \mathrm{ml})$ were collected by venipuncture and transferred into EDTA bottles $(3 \mathrm{ml})$ for onward haematological profile analyses (packed cell volume, PCV; haemoglobin concentration, Hgb; white blood cell count and differentials, WBC), while $2 \mathrm{ml}$ of the whole blood was transferred into heparinised bottles, centrifuged, plasma collected and kept in the fridge at a temperature of $-4 \mathrm{oC}$ prior to biochemical analyses. Renal function (creatinine and urea levels), as well as, liver function (alkaline phosphatise, ALP; aspartate aminotransferase, AST; alanine aminotransferase, ALT).

Questionaire: A questionnaire was design to collect information about the age, sex, marital status, and religion, period of exposure / work period or length, level of awareness, precautionary mode and factors that will improve the health factors of automechanics.

Statistical analysis of data: Results were entered into an excel spread sheet prior to analysis, represented as means \pm SEM and analyzed statistically with the statistical package for social sciences (SPSS) version 16.0 , using the one way students' t-test at $\mathrm{p}=0.05$ ( $95 \%$ confidence interval); $\mathrm{p}<0.05$ was regarded as significantly different. Bar-charts were plotted with Microsoft excel 10.

\section{RESULTS AND DISCUSSION}

Table 1. Renal Function Parameters of Test and Control

\begin{tabular}{lll}
\hline Group & $\begin{array}{l}\text { Urea } \\
(\mathrm{mg} / \mathrm{dl})\end{array}$ & $\begin{array}{l}\text { Creatinine } \\
(\mathrm{mg} / \mathrm{dl})\end{array}$ \\
\hline Control & $16.33 \pm 0.03^{\mathrm{a}}$ & $0.68 \pm 0.03^{\mathrm{a}}$ \\
Test & $18.10 \pm 0.70^{\mathrm{b}}$ & $0.81 \pm 0.03^{\mathrm{b}}$ \\
p-value & $\mathrm{p}=0.037$ & $\mathrm{p}=0.002$
\end{tabular}

Values are represented as mean \pm SEM $(n=30)$. Values with different superscripts are significantly different $(\mathrm{p}<0.05)$ down the column (i.e. between the treatment groups) for each parameters. All the parameters showed statistically significant changes. For the renal function tests, creatinine gave the most significant change. Correlation between urea level and creatinine level. Urea level increases with creatinine $(\mathrm{r}=0.011)$ but there was no correlation between both parameters. 
Table 2. Result of Haematological Parameters for Test and Control

\begin{tabular}{lllll}
\hline Group & $\begin{array}{l}\text { Packed cell } \\
\text { volume }(\%)\end{array}$ & $\begin{array}{l}\text { Haemoglobin } \\
\text { concentration }(\mathrm{g} / \mathrm{dl})\end{array}$ & $\begin{array}{l}\text { Lymphocytes } \\
(\%)\end{array}$ & $\begin{array}{l}\text { Neutrophils } \\
(\%)\end{array}$ \\
\hline Control & $39.90 \pm 0.60^{\mathrm{a}}$ & $13.53 \pm 0.20^{\mathrm{a}}$ & $65.53 \pm 1.00^{\mathrm{a}}$ & $26.40 \pm 0.90^{\mathrm{a}}$ \\
Test & $41.90 \pm 0.80^{\mathrm{b}}$ & $14.32 \pm 0.30^{\mathrm{b}}$ & $65.93 \pm 2.00^{\mathrm{a}}$ & $\begin{array}{l}33.50 \pm 2.00^{\mathrm{b}} \\
\mathrm{p}=0.000\end{array}$ \\
p-value & $\mathrm{p}=0.039$ & $\mathrm{p}=0.036$ & $\mathrm{p}=0.850$ &
\end{tabular}

Values are represented as mean \pm SEM $(n=30)$. Values with different superscripts are significantly different $(\mathrm{p}<0.05)$ down the column (i.e. between the treatment groups) for each parameters. All the parameters showed statistically significant changes apart from lymphocyte. Neutrophils recorded the significant change (increase) for the haematological parameters.

Table 3. Liver function parameters of test and

\begin{tabular}{llll}
\multicolumn{4}{c}{ control. } \\
\hline Group & ALP $(\mathrm{U} / \mathrm{L})$ & AST $(\mathrm{U} / \mathrm{L})$ & ALT $(\mathrm{U} / \mathrm{L})$ \\
\hline Control & $16.60 \pm 1.00^{\mathrm{a}}$ & $13.40 \pm 0.70^{\mathrm{a}}$ & $7.37 \pm 0.50^{\mathrm{a}}$ \\
Test & $19.67 \pm 1.00^{\mathrm{b}}$ & $9.67 \pm 0.60^{\mathrm{b}}$ & $4.80 \pm 0.40^{\mathrm{b}}$ \\
p-value & $\mathrm{p}=0.027$ & $\mathrm{p}=0.001$ & $\mathrm{p}=0.001$
\end{tabular}

Values are represented as mean \pm SEM $(n=30)$. Values with different superscript are significantly different $(\mathrm{p}<0.05)$ down the column (i.e. between the treatment groups) for each parameters. For the liver function tests, all parameters showed statistically significant changes; AST and ALT gave most significant change (decrease).

According to Meinz (1999), spent oil contains heavy metals and polycyclic aromatic hydrocarbons and chemical additives including amines, phenols, benzenes, calcium, zinc, lead, barium, manganese, phosphorus and sulphur which are dangerous to living organisms.

The high level of toxic heavy metals and polycyclic aromatic hydrocarbon which has been reported to be present in spent oil could be attributed to observations of this research (Njoku et al., 2011).

Assessment of renal function status of these subjects (table 1) indicated that plasma urea and creatinine levels for the auto-mechanics $(18 \mathrm{mg} / \mathrm{dl}$ and $0.81 \mathrm{mg} / \mathrm{dl}$, respectively) was significantly higher than the control group $(16 \mathrm{mg} / \mathrm{dl}$ and $0.68 \mathrm{mg} / \mathrm{dl}$, respectively). This is indicative of decrease in the basic renal function, excretion of these wastes, which might precipitate to other renal dysfunction with time. The proportionate increase between urea and creatinine did not show significant correlation by Spearman's correlation $(\mathrm{r}=0.011)$. Though no detailed studies were located regarding renal effects in humans after dermal exposure to used mineral-based crankcase oil. Histopathological analyses of kidneys and urinary bladders from rabbits given dermal applications of $8 \mathrm{~mL} / \mathrm{kg}$ of used mineral-based crankcase oil on a 4-inch-square area of their backs 5 days/week for 2 weeks showed no adverse effects
(API 1980; Beck et al., 1984; Vernot et al., 1990). Ihedioha et al (2009) reported no renal effects.

Table 2 indicates the results for haematological profile of the auto-mechanics compared to the control group; packed cell volume increased significantly (41\%) for test compared to control (39\%); haemoglobin concentration increased significantly $(14.3 \mathrm{~g} / \mathrm{dl})$ compared to control $(13 \mathrm{~g} / \mathrm{dl})$; and neutrophils increased significantly (34\%) compared to the control (26\%). Though, lymphocytes increased (65.9\%) compared to the control $(65.5 \%)$, this was not significant $(\mathrm{p}=0.850)$. The increase in packed cell volume and haemoglobin concentration might be an adaptation to the stress induced by the spent engine oil on oxygen carriage from the lungs, transport in vessels and deliverance to tissues. Clausen and Rastogi (1977) made a contrary report. However, neutrophils $(\mathrm{p}<0.05)$ and lymphocytes $(\mathrm{p}=0.850)$ increased for the test (33.5\% and $65.9 \%$, respectively) compared to the control $(26.4 \%$ and $65.5 \%$, respectively). These increases could be attributed to the stimulation of immune response by the toxic components of the spent engine oil.

The liver function parameters represented by table 3 , indicates an increase in ALP activity for the test (19.7U/l) compared to the control (16.6U/1). This significant increase suggests a possible development of hepato-biliary cholestasis in the auto-mechanics which might be time dependent. This is agreement with Clausen and Rastogi (1977) and Ihedioha et al (2009). On the contrary, AST and ALT significantly decreased (13.4U/1 and 7.4U/1, respectively) compared to the test (9.7U/1 and 4.8U/1, respectively).

Conclusion:: From the salient observations made from the research, it becomes very important that government and other stake holders in Nigeria health sector and communication media should rise up to challenge of providing detailed data base on the use, constituents, health and environmental hazards of spent engine oil. This information should be made readily available in local Nigerian languages for better communication so that auto-mechanics, other users and exposed individuals can be better informed and enlightened on the possible dangers of exposure to spent engine oil. Auto-mechanics are also advised to observe good hygiene protocol of keeping their tools, work cloths, and environment as neat as possible. They should also make the washing of their arms a regular habit. That notion that, "auto- 
mechanics are usually dirty, unkempt and unhygienic individuals" should be done away with. The use of face mask are thus encouraged to protect the eyes, nose and mouth, and as well, prevent the passage of spent engine oil (and its effluents) through these channels into the body. Conclusively, auto-mechanics should also visit health centres and clinics for regular checkups.

Acknowlegdement: We hereby acknowledge the automechanics of Second East circular, Benin City especially the representative head of the community for their understanding, support and compliance during the research period. The medical Staff of Sama polyclinic, Second East circular road, Benin City, Edo state is not left out for their unflinching support both in the laboratory and contribution of medical expertise.

\section{REFERENCES}

Akanji, M A, Olagoke, O A. and Oloyede, O B. (1993). Effect of chronic consumption of metabiosulphate on the integrity of rat kidney cellular system, Toxicology 81: $173-179$.

API. (1980). Acute Toxicity Tests: API 79-7 Used Composite Motor Oil, American Petroleum Institute (API), Publication, 1980, No. 27-32772, Washington DC.

ATSDR (Agency for Toxic Substances and Disease Registry) (1997). Toxicological Profile for mineral base crankcase oil. Atlanta, GA: Department of Health and Human Services, Public Health Service Press.

Beck, L S, Hepler, D I. and Hansen, K L. (1984). The acute toxicology of selected petroleum hydrocarbons, In: Mac Farland HN (ed) Co.

(Advances in Modern

Environ ment a 1

Toxicology, Vol.16: Applied

Toxicology of Petroleum

Hydrocarbons. Princeton Scientific, Princeton) $1-16$.

Boffetta, P, Jourenkova, N. and Gustavsson, P. (1997). Cancer risk from occupational and environmental exposure to polycyclic aromatic hydrocarbons. Cancer causes control 8(3): 444-472.

Clausen, J. and Rastagi, S. (1977). Heavy metal pollution among autoworkers: 1. Lead. British J Industrial Med 34: $208-215$.

Collins, C. (2007). Implementing phytoremediation of petroleum hydrocarbons, In: Willey, N. (Ed), (Human Press Incorporated: New Jersey) $99-108$.
Dautrebande, L and Capps, E R. (1950). Arch. intern. Pharmacodynamie 82: 505.

Dautrebande, L, Shaver, L. and Capps, R. (1951). Studies on aerosols. Influence of particulate matter on eye irritation produced by volatile irritants and importance of particle size in connection with atmospheric pollution. Arch. Inter. Pharmacodyn 85: 17-48.

Hu, Z. and Wells, P G. (1994). Modulation of benzo(a)pyrene bioactivation by glucuronidation in peripheral blood lymphocytes from rats with a genetic deficiency in bilirubin UDP-glucuronosyltransferases. Toxicol. Appl. Pharmacol 127: 306-313.

Ihedioha, J I, Iwuogo, M U. and Ihedioha, T E. (2009). Haematological and clinical chemistry findings associated with sub-acute contamination of drinking water with varied low percentages of used engine oil. Comparative clinical pathology 18 (2): 169-176.

Ingram, R E, Bernet, C Z. and Mc Laughlin, S C. (1994). Attentional allocation processes in individuals at risk for depression. Cognitive Therapy and Research. 18: 317-332.

Kojernikova, Y V (1999). Rational ways of preparation of dispensed oil system. Russian oil and Gas University, Moscow. Ph. D. thesis (Unpublished). P.133.

Meinz, V (1999). Used oil characterization study. Washington State Department of ecology solid and hazardous waste program, Pp. 19.

Njoku, K L, Akinola, M O. and Busari, T O. (2012). Effect of time of application of spent oil on the growth and performance of maize (Zea mays). African Journal of Environmental Science and Technology 6(1): 67-71.

Nygren, P A, Stahl, S. and Uhlen, M. (1994). Trends Biotechnol 12: 184-188.

Odjegba, V J and Atebe, J O (2007). The effect of used oil on carbohydrate, mineral content and nitrate reductase activity of leafy vegetable (Amaranthus hybridus L.). Journal of Applied Sciences and Enviromental Management 11(2): 191-196.

Pachathundikani, S K and Varghese E T (2006). Blood zinc protoporphyrin, serum total protein and total cholesterol levels in automobile workshop workers in relation to lead toxicity: Our experience. Indian Journal of Clinical biochemistry 21: 114-117.

Page, N P and Mehlman, M (1989). Health effects of gasoline refueling vapors and measured exposures at service stations. Toxicol. Ind. Health 5: 869-890.

Van, Donkelaar (1990). Environmental Effects of Crankcase and Mixed-Lubrication. Sci. Total Environ 92: 165-179.

Vemot, E H, Drew, R T and Kane, M L (1990). Acute toxicologic evaluation of used motor oil. Acute Toxic Data 1: 167 -169. 